\title{
Examination of the Usage of a New Beak-Abrasive Material in Different Laying Hen Genotypes (Preliminary Results)
}

\author{
Tamás Péter Farkas ${ }^{1, *}$, Attila Orbán ${ }^{2}$, Sándor Szász ${ }^{1}$, András Rapai ${ }^{1}$, Erik Garamvölgyi ${ }^{1}$ and Zoltán Sütő ${ }^{1}$ \\ 1 Institute of Animal Science, Hungarian University of Agriculture and Life Sciences, Guba Sándor Str. 40, \\ H-7400 Kaposvár, Hungary; szasz.sandor@uni-mate.hu (S.S.); rapaiandras123@gmail.com (A.R.); \\ garamvolgyi.erik@uni-mate.hu (E.G.); suto.zoltan@uni-mate.hu (Z.S.) \\ 2 Bábolna TETRA Ltd., Radnóti Miklós Str. 16, H-2943 Bábolna, Hungary; orbanattila@babolnatetra.com \\ * Correspondence: farkas.tamas.peter@uni-mate.hu; Tel.: +36-7-0775-4633
}

Citation: Farkas, T.P.; Orbán, A.; Szász, S.; Rapai, A.; Garamvölgyi, E.; Sütő, Z. Examination of the Usage of a New Beak-Abrasive Material in Different Laying Hen Genotypes (Preliminary Results). Agriculture 2021, 11, 947. https://doi.org/ 10.3390/agriculture 11100947

Academic Editor: Vincenzo Tufarelli

Received: 20 July 2021

Accepted: 24 September 2021

Published: 29 September 2021

Publisher's Note: MDPI stays neutral with regard to jurisdictional claims in published maps and institutional affiliations.

Copyright: (c) 2021 by the authors. Licensee MDPI, Basel, Switzerland. This article is an open access article distributed under the terms and conditions of the Creative Commons Attribution (CC BY) license (https:// creativecommons.org/licenses/by/ $4.0 /)$.
Abstract: The aim of the experiment was to investigate the use and effect of a new beak-abrasive material not yet examined on mortality of non-beak trimmed laying hens of different genotypes housed in an alternative pen. The study was performed on 636 females belonging to three genotypes of Bábolna TETRA Ltd. (a1 = commercial brown layer hybrid (C); a2 = purebred male line offspring group (maternal); a3 = purebfigure ed female line offspring group (paternal)). A total of 318 hens, i.e., 106 hens/genotype distributed in six pens (53 hens/pen), were evaluated. Cylindrical beak-abrasive blocks of 5.3-5.6 kg were suspended (0.1-0.4 mm diameter gravel, limestone grit, lime hydrate, and cement mixture) in six alternative pens. In six control pens without abrasive material, 318 hens, i.e., 106 hens /genotype ( 2 pens control group/genotype, i.e., $\mathrm{C} 1$ = commercial brown layer hybrid, C2 = purebred male line offspring group, C3 = purebred female line offspring group; 53 hens (pen;) were placed where there were no beak-abrasive materials. The rate of change in the weight of the beak-abrasive materials and the mortality rate were recorded daily. In the six pens equipped with beak-abrasive materials, infrared cameras were installed, and $24 \mathrm{~h}$ recordings were made. The number of individuals pecking the beak-abrasive material, the time and duration of dealing with the material were recorded. Data coming from one observation day are given. During the 13 experimental weeks of observation, the weight loss of beak-abrasives differed significantly in the different genotypes ( $\mathrm{a} 1=27.4 \%$; $\mathrm{a} 2=29.6 \%$; $\mathrm{a} 3=56.6 \%$ ). During the only day analyzed, the hens from all the genotypes mostly stayed between 17:00 and 21:00 $\mathrm{h}$ in the littered scratching area where the beak-abrasive material was placed ( $1=48.4 \%$; a2 $=49.2 \% ; \mathrm{a} 3=54.4 \%$ ). In the case of each genotype, the rate of the hens dealing with beak-abrasives in the first two periods of the day was relatively low $(0.2 \%-0.7 \%)$. Peaks of the activity were between 17:00 and 21:00 ( $\mathrm{a} 1=0.8 \%$; $\mathrm{a} 2=1.3 \%$; $\mathrm{a}=1.8 \%$ ). The a3 dealt with the beak-abrasive materials to a significantly greater extent in the period from $13: 00$ to $17: 00(0.8 \%)$ and from $17: 00$ to $21: 00(1.8 \%)$ than the a1 $(0.2 \%$ and $0.8 \%$, respectively). Due to the use of the beak-abrasive materials, the mortality rate decreased the most in the genotypes that used them (a1 with beak-abrasive material 0.0\% vs. C1 9.4\%; a2 with beak-abrasive material $2.9 \%$ vs. C2 $12.4 \%$; a3 with beak-abrasive material) $15.4 \%$ vs. C3 5.7\%). It can be concluded that the insertion of beak-abrasive materials increased the behavioral repertoire of hens, which is particularly beneficial from an animal welfare point of view. Further and longer-term research is needed to determine whether the insertion of the beak-abrasive material has a beneficial effect on the mortality data of the experimental groups through enrichment, either through physical abrasion of the beak or both.

Keywords: laying hen; non-caged; non-trimmed; beak abrasion; behavior; aggressiveness; mortality

\section{Introduction}

The examination of the abrasive material is actual nowadays; that is why the alternative husbandry technologies are increasingly gaining prominence in European laying 
hen farming, in which the abandonment of beak trimming is encouraged [1]. In addition, a significant proportion of consumers want to eat eggs from a husbandry technology where the hens live in a larger area, in more stimulus-rich conditions, without beak trimming.

In general, those who advocate the preamble of alternative housing systems and the abandonment of beak trimming are referred to the behavior of wild hen species (junglefowl) in their natural environment. In its natural environment, one of the ancestors of domestic hens (Gallus gallus domesticus) is the red junglefowl (Gallus gallus or Gallus ferrugineus) searching for food, which is also assisted by the beak [2]. Their beaks constantly make contact with materials of different hardness in the environment while they search for food. This activity is carried out almost throughout the whole day, from which it follows that their beaks are subject to constant friction and wear.

This natural process does not apply in this form to layer hybrids kept in cages. They do not have to search for food, as it is at their disposal within a few meters, and they do not have the same substances in the cages as in nature for the wear of their beaks [3].

Laying hens in alternative housing systems usually live in large groups but in limited places and environments, and their lack of stimuli can lead to abnormal behaviors and cannibalism due to abandonment of the beak trimming.

Unfortunately, aggression and cannibalism may be higher in non-beak trimmed flocks, which may result in higher mortality rates, as well as higher rates of egg breakage and feed waste $[4,5]$. For this reason, beak trimming of hens is widely used [6,7], which solved these problems somewhat [8], both in alternative systems [9] and cage housing [10]. However, it should be mentioned that there are several negative effects of beak trimming. Beak shortening can cause tissue and nerve damage [11], which may result in abnormalities that may inhibit the hen from feathering [12-15] and feeding [16], furthermore may have a negative effect on body weight [17] and egg production. Moreover, the shortened beak is not fully capable of performing its function against ectoparasites [18-20]. These changes not only jeopardize the welfare of the hens but can also be a serious economic loss for the producers [21]. Partly because of these, beak trimming is now banned in Norway (1974), in Finland (1986), in Sweden (1988), and Denmark (2013) due to the pressure of animal welfare organizations, commercial interest groups, and certain sections of the consumers. Other countries, such as Germany (from 2017) and England (scheduled for 2025), have initiated voluntary agreements to phase out the practice of beak trimming. Belgium, Luxembourg, Switzerland have urged for stricter animal welfare laws. This practice was banned in Austria as early as 2013 and has been banned in The Netherlands since 1 September 2018 [1].

Based on these facts, it would be desirable to try other alternative solutions that facilitate beak wear and enrich the environment for laying hens, which can reduce the adverse effects of long sharp beaks on production. In addition, adequate environmental enrichment would also be important for laying hens, which can diversify the environment of the animals, thus broadening the behavioral repertoire and reducing the incidence of abnormal behaviors.

Without beak trimming, an excellent way to promote natural beak wear is inserting various beak-abrasive materials into the place where the animals are kept, which can simultaneously be an enriching element, an opportunity to reduce aggression and wear the beak.

Therefore, in our research, we aimed to investigate the use and effect of a new, hitherto unexamined beak-abrasive material on mortality and aimed to investigate the behavior and location during the different parts of the day for non-beak trimmed laying hens of different genotypes housed in an alternative pen.

\section{Materials and Methods}

The study was conducted at the Poultry Testing Station (Kaposvár, HU, Somogy) of the Kaposvár Campus Training and Experimental Plant of Hungarian University of Agriculture and Life Sciences, with a herd of three different genotypes of laying hens provided by Bábolna TETRA Ltd (Bábolna, Hungary). (a1 = commercial brown layer hybrid (K); 
a2 = purebred male line offspring group (maternal); a3 = purebred female line offspring group (paternal)) (Figure 1). The set numbers are: $\mathrm{N}=636 ; \mathrm{n}=212$ hen/genotype; $53 \mathrm{hen} /$ pen. The laying hens were not beak trimmed. The barn typically had a temperature of $15-18{ }^{\circ} \mathrm{C}$ and humidity between $65 \%$ and $70 \%$. Lighting of $16 \mathrm{~h}$ (continuously between 5:00 and 21:00; 30 LUX, warm white) per day was used during the experimental period. Laying hens were allowed to consume ad libitum commercially available hen feed $(175.1 \mathrm{~g} / \mathrm{kg}$ of CP, $39.8 \mathrm{~g} / \mathrm{kg}$ of CF, $11.50 \mathrm{MJ}$ of ME, $34.2 \mathrm{~g} / \mathrm{kg}$ of $\mathrm{Ca}, 5.4 \mathrm{~g} / \mathrm{kg}$ of P, $8 \mathrm{mg} / \mathrm{kg}$ of $\mathrm{Cu}, 80 \mathrm{mg} / \mathrm{kg}$ of Zn, $50 \mathrm{mg} / \mathrm{kg}$ of Fe, $100 \mathrm{mg} / \mathrm{kg}$ of Mn, $1 \mathrm{mg} / \mathrm{kg}$ of I, $0.3 \mathrm{mg} / \mathrm{kg}$ of Se) from 2 suspended hand-filled feeders (trough length: $120 \mathrm{~cm}$ ) and drinking water from a suspended open water drinker (trough length: $120 \mathrm{~cm}$ ) in each pen (Figure 2).

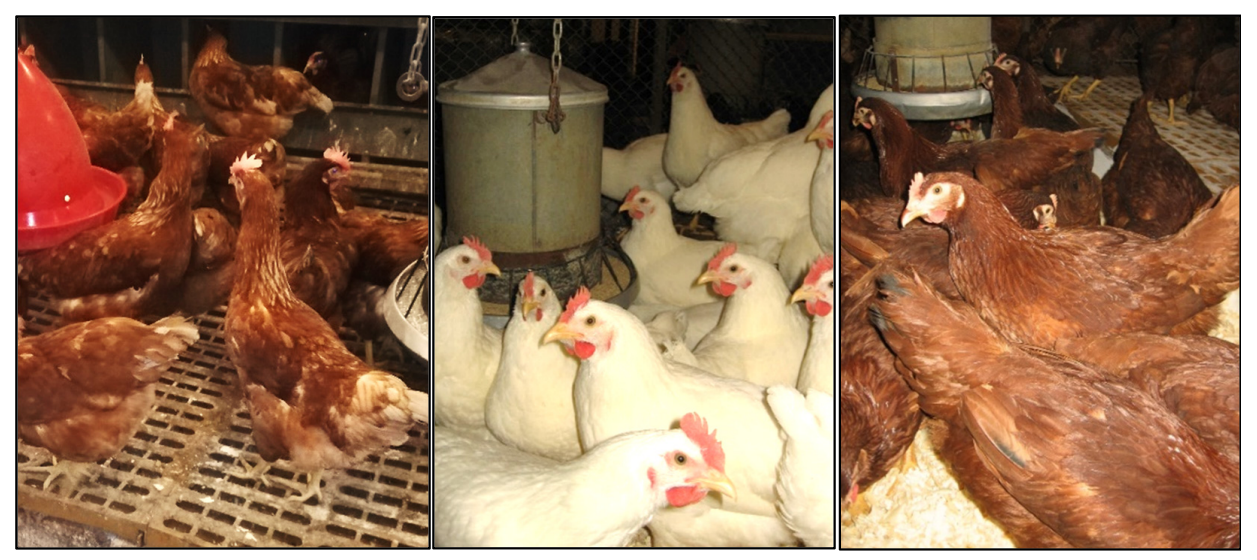

Figure 1. Experimental stocks with three different genetic backgrounds (commercial hybrid (left), purebred offspring of maternal (in the middle) and paternal lines (right)).
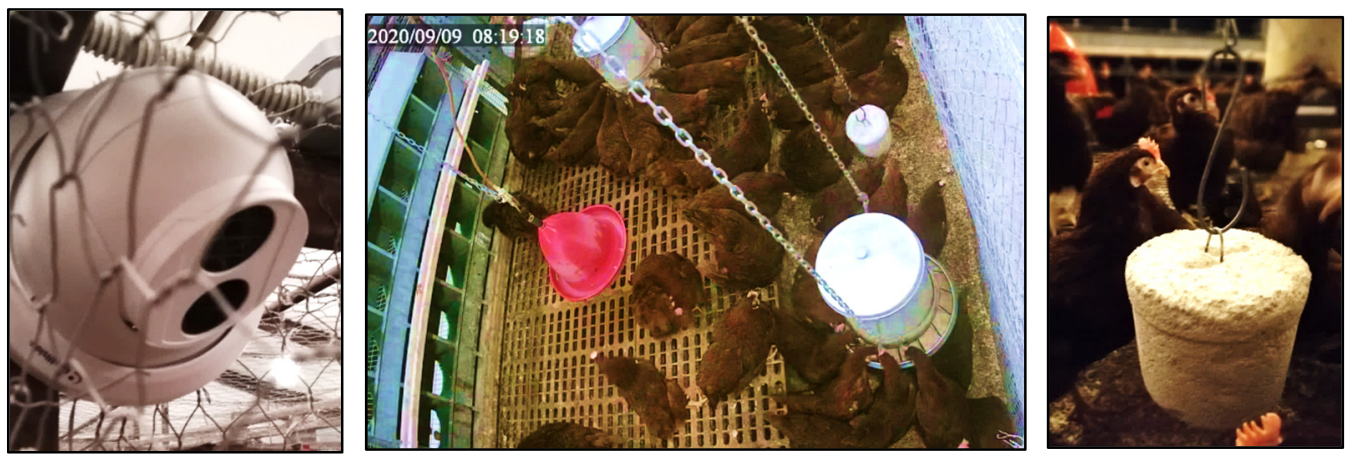

Figure 2. Infrared camera installed in the pen; HD-quality recording; pen interior layout with suspended beak wear material.

A total of 53 nineteen-week-old pullets $(1041 \mathrm{~cm} 2 / \mathrm{hen})$ were housed in the 12 alternative pens, each with a floor area of $5.52 \mathrm{~m} 2$. In each pen, $1 / 3$ of the floor space consisted of a scratching area littered with wood shavings, while the remaining $2 / 3$ of the floor space consisted of an elevated plastic grid floor (Figure 2).

There were provided 14 laying nests with artificial grass placed on two levels per pen for the hens ( 3.8 hens/nest). In front of the laying nest row, 2 perches per level helped approach the nests. Cylindrical beak-abrasive blocks of $5.3-5.6 \mathrm{~kg}(0.1-0.4 \mathrm{~mm}$ diameter gravel, a mixture of limestone grit, lime hydrate, and cement) were hung above the scratching area (Figure 1) in six pens (2 pens/genotype) identified as a1, a2 and a3 for genotype. The beak-abrasive blocks were provided to us by Bábolna TETRA Ltd(Bábolna, Hungary). and were manufactured by the company itself. We adjusted the height of the beak-abrasive blocks so that their center fell into the back height of the laying hens. For each observed pen, we recorded daily the rate of block weight change (loss) and hens mortality rate of 
the abrasive. As a control group, no beak-abrasives were placed in 6 pens ( 2 pens control group/genotype, i.e., C1, C2, C3).

Infrared cameras (GeoVision Target(Budapest, Hungary) H.265 4.0 Mpixel outdoor IP Eyeball dome camera) were installed over the 6 pens equipped with abrasive materials, and $24 \mathrm{~h}$ recordings were made on the test week using special software (GeoVision GV-NVR System) (Budapest, Hungary).

Flock monitoring and data collection began at week 24 of life after 5 weeks of adaptation and production. To date, a total of 13 study weeks have been evaluated. On each study day, the location and activity of the hens within the pen were recorded and observed every quarter hours (96 times per day). In our research presenting the preliminary results, we have so far evaluated one day in two repeats per genotype, which meant the analysis of a total of $(1 \times 3 \times 2 \times 96=) 576$ recordings.

Analyzing the camera footage, we calculated the time proportion of hens spent in the laying nests, perch, plastic grid floor, and scratching area. In addition, we also recorded the activity of the birds in the different compartments, i.e., differentiated between eating, drinking, scratching, resting-feathering behavior, and the use of abrasive material.

The weight change of all beak-abrasive blocks was measured daily. For the pen paternal), which produced the greatest weight loss, a complete lighting period, i.e., $16 \mathrm{~h}$ were observed without interruption. The number of individuals 'dealing' with the beak-abrasive materials, the date and duration of dealing with the substance were recorded. Dealing with the beak-abrasive material means: The hens touch only the blocks with their beak to feed or any other reason.

Based on this, three categories were distinguished:

1. The individual's attention is only drawn to one or two pecks, after which they continue to search for another activity;

2. The individual pecks more than two times, using the abrasive for 5-10 s;

3. The birds peck it several times and use it for at least $15 \mathrm{~s}$.

The degree of abrasion of the beak-abrasive blocks, the location of the hens, and the distribution of different behaviors, as well as the mortality rate, were evaluated by the likelihood ratio test using the SPSS 10.0 software package.

\section{Results and Discussion}

\subsection{The Degree of Weight Change of the Abrasive Materials}

A statistically verifiable difference was observed in the extent of weight loss of the measured beak-abrasive materials between the examined genotypes (Table 1). The slightest weight loss was observed in the commercial hybrid; little more was measured in the maternal genotype. In contrast, for the paternal genotype, more than $56 \%$ of the abrasive material was depleted during the study period. In this period, the paternal genotype dealt the most with the beak-abrasive material and wore the largest proportion of it. This observation is strongly correlated with the results in Table 4, which show that this group had the lowest mortality.

Table 1. Extent of weight loss of beak-abrasive materials in the case of different genotypes over a 13-week study period (\%).

\begin{tabular}{lcccc}
\hline & Commercial Hybrid $\mathbf{a}_{1}$ & Maternal $\mathbf{a}_{2}$ & Paternal $^{\mathbf{a}_{3}}$ & Prob. \\
\hline Extent of weight loss & $27.42^{\mathrm{a}}$ & $29.60^{\mathrm{b}}$ & $56.61^{\mathrm{c}}$ & $<0.001$ \\
\hline $\mathrm{a}, \mathrm{b}, \mathrm{c}$ indicate significant differences among the different genotypes $(p<0.05)$. &
\end{tabular}

\subsection{Location and Behavior of Laying Hens, Dealing with Abrasive Material}

In order to explore in more detail the background of the laying hen's handling of beak-abrasive materials, we need to know the location of the animals in the pen at a given time of day because a higher degree of expression of the specific behavioral repertoires, 
characteristic for a given part of the pen, is expected when there is a greater presence of animals in it.

Table 2 shows the percentual distribution of laying hens between different parts of the laying hen house depending on genotype and time of day. For all the genotypes examined, it is clear that only in the last light period of the day, i.e., between 17:00 and 21:00, the laying hens were staying the most in the littered scratching area, where the beak abrasion material was also suspended. In the case of the paternal genotype, there were significantly more laying hens in the litter scratching area than on the grid floor, which is consistent with the data in Table 3 and Figures 3 and 4. The only interesting difference in terms of location data is that the maternal genotype was much more in the scratching area during the dark period than the other two genotypes.

Table 2. Percentual distribution of laying hens among different parts of the pen depending on genotype and time of day (\%).

\begin{tabular}{|c|c|c|c|c|c|}
\hline \multirow{2}{*}{$\begin{array}{c}\text { Periods of the } \\
\text { Day }\end{array}$} & \multicolumn{5}{|c|}{ Distribution of Location Choice of Laying Hens, \% } \\
\hline & In the Nest & On the Perches & $\begin{array}{l}\text { On the Plastic } \\
\text { Grid Floor }\end{array}$ & $\begin{array}{c}\text { Littered } \\
\text { Scratching Area }\end{array}$ & Prob. \\
\hline & \multicolumn{5}{|c|}{ Commercial hybrid $\mathrm{a}_{1}$} \\
\hline 5:00-9:00 & $5.4^{\mathrm{aD}}$ & $6.5^{\mathrm{aC} 2}$ & $48.6^{\mathrm{cA}}$ & $39.5^{\mathrm{bB} 1}$ & $<0.001$ \\
\hline 9:00-13:00 & $2.7^{\mathrm{aC} 2}$ & $7.4^{\mathrm{bC} 3}$ & $52.5 \mathrm{~dB} 1$ & $37.4^{\mathrm{cB}}$ & $<0.001$ \\
\hline 13:00-17:00 & $0.0^{\mathrm{aA} 1}$ & $6.7^{\mathrm{bC} 3}$ & $54.2^{\mathrm{dB} 2}$ & $39.0^{\mathrm{cB} 1}$ & $<0.001$ \\
\hline $17: 00-21: 00$ & $0.7^{\mathrm{aB} 2}$ & $3.9^{\mathrm{bB} 2}$ & $47.0^{\mathrm{cA}}$ & $48.4^{\mathrm{cC} 1}$ & $<0.001$ \\
\hline $21: 00-5: 00$ & $1.9^{\mathrm{aC} 2}$ & $2.8^{\mathrm{bA3}}$ & $87.7^{\mathrm{dC} 2}$ & $7.5^{\mathrm{cA} 1}$ & $<0.001$ \\
\hline \multirow[t]{2}{*}{ Prob. } & $<0.001$ & $<0.001$ & $<0.001$ & $<0.001$ & - \\
\hline & \multicolumn{5}{|c|}{ Paternal $\mathrm{a}_{2}$} \\
\hline 5:00-9:00 & $4.0^{\mathrm{bD}}$ & $2.4^{\mathrm{aC} 1}$ & $47.8^{\mathrm{cB}}$ & $45.8^{\mathrm{cC} 2}$ & $<0.001$ \\
\hline 9:00-13:00 & $1.5^{\mathrm{aC} 1}$ & $1.9^{\mathrm{aBC} 1}$ & $56.8^{\mathrm{cC} 2}$ & $39.7^{\mathrm{bB}}$ & $<0.001$ \\
\hline $13: 00-17: 00$ & $0.2^{\mathrm{aB} 2}$ & $1.7^{\mathrm{bBC} 1}$ & $50.4^{\mathrm{cB} 1}$ & $47.7^{\mathrm{cC} 3}$ & $<0.001$ \\
\hline $17: 00-21: 00$ & $0.1^{\mathrm{aB} 1}$ & $1.3^{\mathrm{bB} 1}$ & $44.2^{\mathrm{cA}}$ & $54.4^{\mathrm{dD} 2}$ & $<0.001$ \\
\hline $21: 00-5: 00$ & $0.0^{\mathrm{aA} 1}$ & $0.0^{\mathrm{aA} 1}$ & $87.4^{\mathrm{cD} 2}$ & $12.6^{\mathrm{bA} 2}$ & $<0.001$ \\
\hline \multirow[t]{2}{*}{ Prob. } & $<0.001$ & $<0.001$ & $<0.001$ & $<0.001$ & - \\
\hline & \multicolumn{5}{|c|}{ Maternal $\mathrm{a}_{3}$} \\
\hline 5:00-9:00 & $5.1^{\mathrm{aC}}$ & $5.9^{\mathrm{aC} 2}$ & $47.9^{\mathrm{cAB}}$ & $41.1^{\mathrm{bAB} 1}$ & $<0.001$ \\
\hline $9: 00-13: 00$ & $4.1 \mathrm{aC} 3$ & $5.2^{\mathrm{aC} 2}$ & $50.1^{\mathrm{CB} 1}$ & $40.5^{\mathrm{bAB}}$ & $<0.001$ \\
\hline $13: 00-17: 00$ & $1.6^{\mathrm{aAB} 3}$ & $4.8^{\mathrm{bBC} 2}$ & $50.2^{\mathrm{dB} 1}$ & $43.4^{\text {cB2 }}$ & $<0.001$ \\
\hline $17: 00-21: 00$ & $1.0^{\mathrm{aA} 2}$ & $3.6^{\mathrm{bB} 2}$ & $46.3^{\mathrm{cA}}$ & $49.2^{\mathrm{cC} 1}$ & $<0.001$ \\
\hline $21: 00-5: 00$ & $1.9^{\mathrm{aB} 2}$ & $1.9^{\mathrm{aA} 2}$ & $56.3^{\mathrm{cC} 1}$ & $39.8^{\mathrm{bA} 3}$ & $<0.001$ \\
\hline Prob. & $<0.001$ & $<0.001$ & $<0.001$ & $<0.001$ & - \\
\hline
\end{tabular}

$\mathrm{a}, \mathrm{b}, \mathrm{c}, \mathrm{d}$ indicate significant differences among the different parts of the pen $(p<0.05)$; $\mathrm{A}, \mathrm{B}, \mathrm{C}, \mathrm{D}$ indicate significant differences among the different periods of the day $(p<0.05)$; $1,2,3$ indicate significant differences among the different genotypes $(p<0.05)$.

Overall, the laying hens frequently used the littered scratching area and also scratched there because the hen's natural behavior and instinct include searching and scratching for food [22].

To determine the extent of dealing with beak-abrasive material, we gathered important information about the animals' total daily behavioral repertoire, and this way, we assessed the extent to which this activity occurs relative to other behaviors. Moreover, the daily change and rhythm of each form of behavior also have an effect on the development of the handling of the beak-abrasive materials, as this activity satisfies a "secondary" need for poultry, as eating, drinking, and laying eggs are basic needs and behavior.

For all the studied genotypes, a statistically verifiable difference was obtained between the different behaviors for all periods, and daily fluctuations were also observed between the periods (Table 3). Interestingly, compared to other behaviors, dealing with the beakabrasive material represents a significantly lower rate at most times of the day. For all genotypes, the usage of beak-abrasives in the first two periods of the day showed relatively low levels. 
Table 3. Distribution of different behaviors (\%) in several parts of the pen depending on genotype and period of the day.

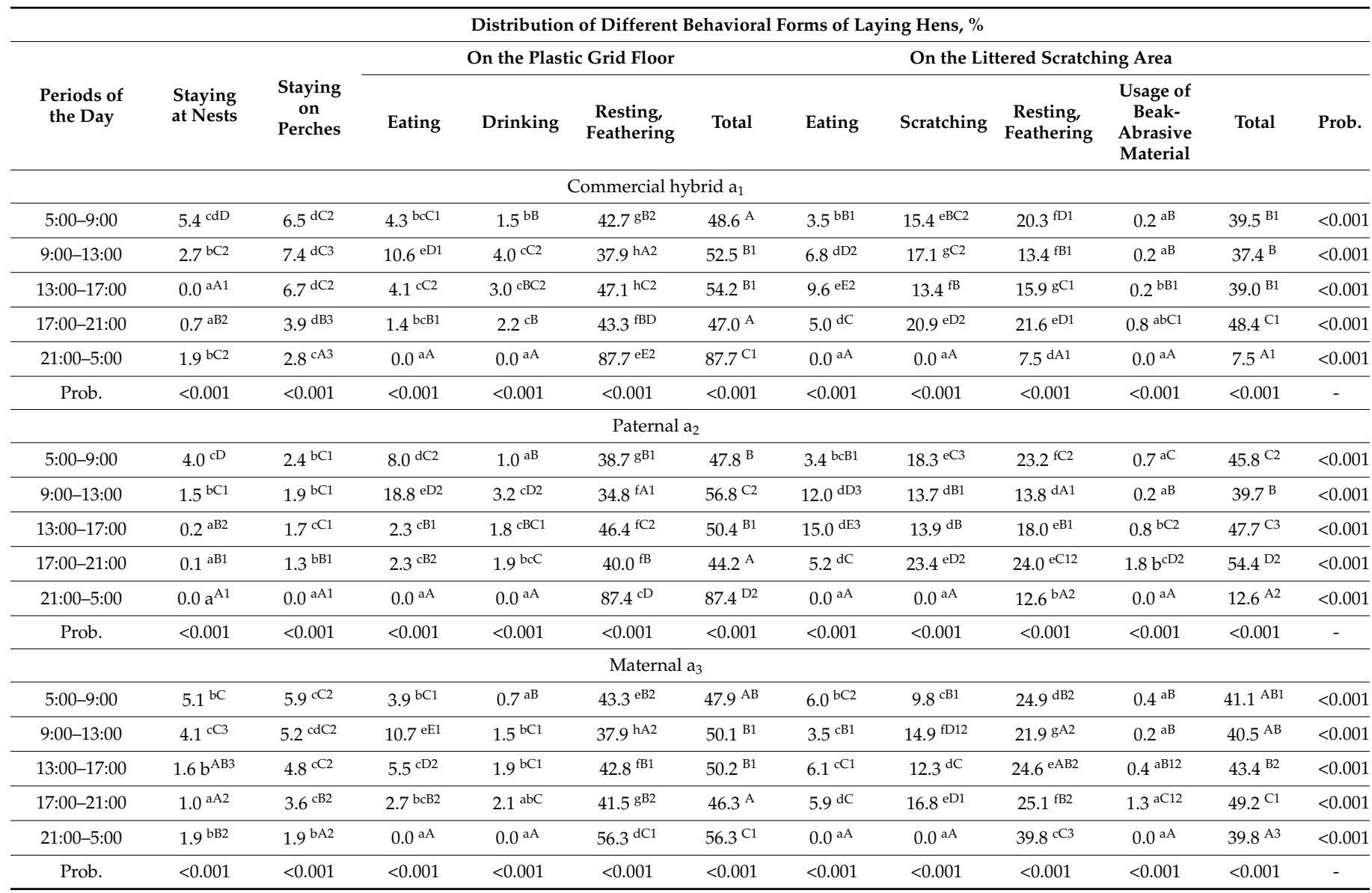

$\mathrm{a}, \mathrm{b}, \mathrm{c}, \mathrm{d}, \mathrm{e}, \mathrm{f}, \mathrm{g}$ indicate significant differences among the different behavioral forms $(p<0.05)$; ${ }^{\mathrm{B}}, \mathrm{B}, \mathrm{C}, \mathrm{D}, \mathrm{E}$ indicate significant differences among the different periods of the day $(p<0.05) ;{ }^{1,2,3}$ indicate significant differences among the different genotypes $(p<0.05)$.

At that time, only $0.2-0.7 \%$ of the flock dealt with the beak-abrasive material on average. The peak of dealing with this fell on the time of the day from 17:00 to 21:00. From the data, it can be clearly seen that compared to the morning hours, the rate of usage of beak-abrasives increased four times in the case of the commercial hybrid, two and a half times in the case of the paternal genotype, and more than three times in the case of the maternal genotype. In the case of the paternal offspring group, the extent of dealing with the beak abrasion material had already exceeded the extent of staying in the laying nest during the last light hours of the day.

The paternal genotype dealt with the beak-abrasive material to a significantly greater extent during the days from 13:00 to 17:00 and from 17:00 to 21:00 than the commercial genotype, which also coincided with the data of the weight loss of the beak-abrasive materials. It can also be seen from Table 3 that the proportion of eating behavior was the lowest in the period from 17:00 to 21:00, so that the proportion of laying hens engaged in scratching and using beak-abrasive materials was increased during this period.

The use of beak-abrasive material showed daily fluctuations for all genotypes. Researching the background of the phenomenon, we examined in more depth the development of the use of the abrasive in the pen where the greatest weight loss (Paternal) was experienced since in this pen we had the opportunity to observe this activity the most (Figure 3).

The deal with the beak-abrasive material was observed first in the morning. It can be said that the abrasive block aroused the interest of mainly one individual at a time, less often two, and even less often three or four hens. 


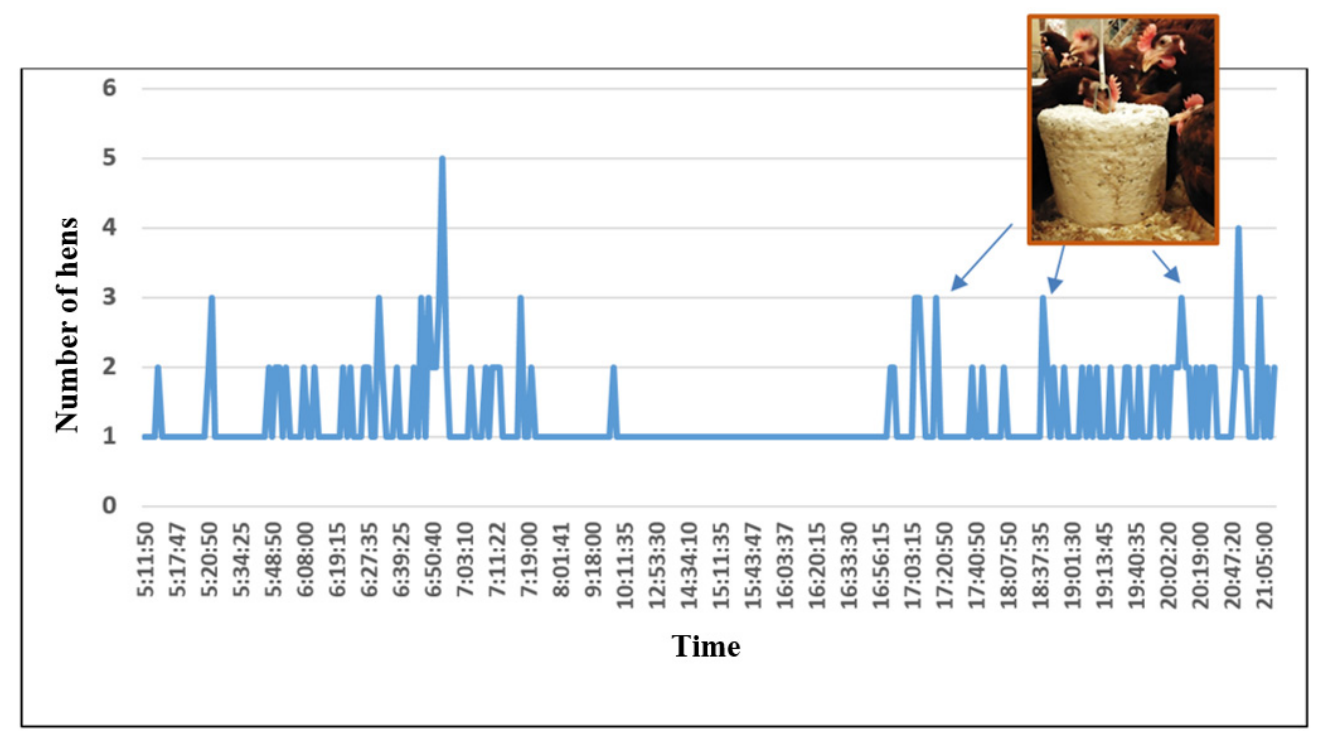

Figure 3. Changes in the number of laying hens using beak-abrasives at different times of the day for the paternal genotype.

The duration of beak-abrasive material showed daily fluctuations also (Figure 4). In the morning, before 8:00 a.m., the feeders are usually empty, in which case the laying hens are hungry and, in addition to scratching, the beak-abrasive materials are also pecked. According to the work schedule, feeding takes place around 8:00 a.m.; when the animals concentrate on feed intake with rather high intensity, their activity is mainly determined by this. In this case, the number of individuals dealing with the abrasive material decreases significantly, and next time their number increased only after 17:00.

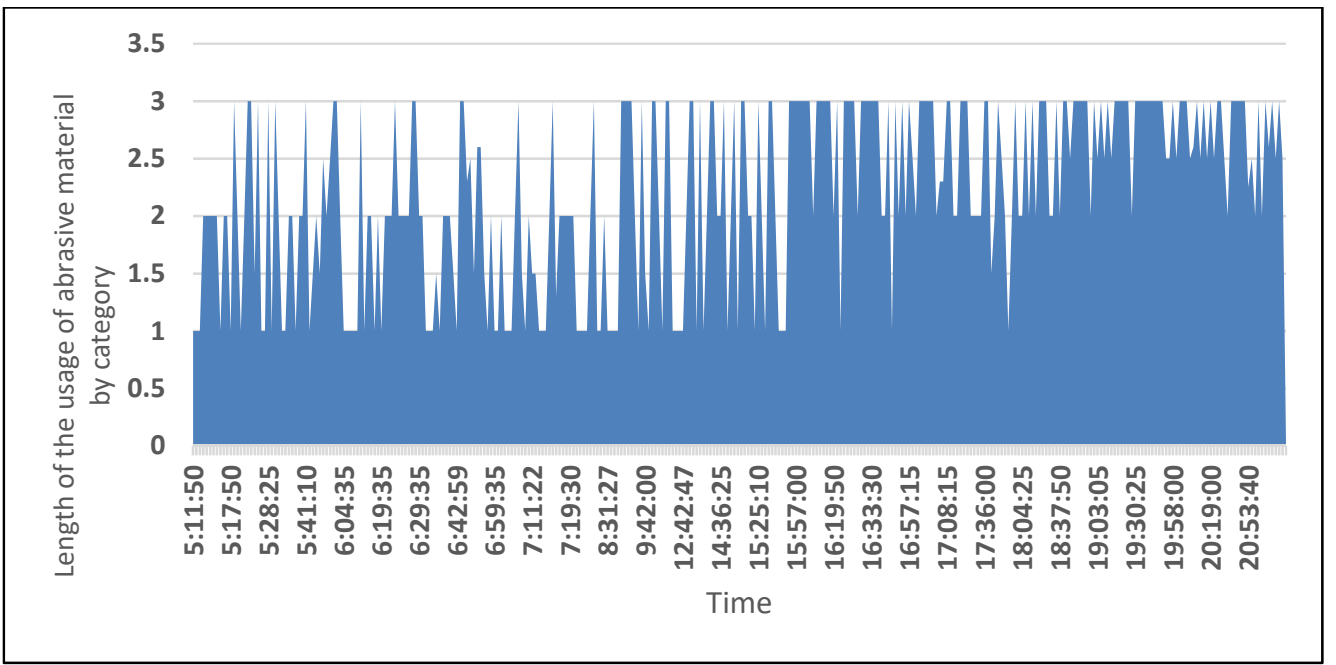

Figure 4. Changes in the duration of dealing with abrasive material at different times of the day in the case of paternal genotype.

Mainly in the early morning hours before feeding, categories 1, 2 were typical, i.e., the hens showed a lower level of interest in the abrasive, which means that they pecked up to one or two and used them for about $10 \mathrm{~s}$. Similar to Figure 3 , not only did the number of individuals dealing with abrasive material increase after 16:00, but also the duration of treatment with abrasive material. At that time, the hens used abrasive materials more frequently and longer. In the evening hours, i.e., after 19:00, category 3 was predominantly observed. 


\subsection{Mortality of Laying Hens Depending on the Use of the Beak Abrasion}

In terms of mortality, a significant difference was observed between the genotypes, both in pens with and without beak abrasion material (Table 4). In the case of the commercial hybrid and the paternal genotype, mortality was significantly lower in pens using beak-abrasives, presumably because this enriching element was used by the animals, which could reduce aggression toward each other and cannibalism, and thus, the resulting mortality was also reduced. This enrichment had a positive effect on laying hens, as noted by some researchers [23,24]. We came to similar results as another study [25], where, as an environmental enrichment, brightly colored bottles, balls, and rattles were placed among the laying hens, the hens began pecking them with their beaks, an activity that reduced the stress accumulated in the animals and helped to reduce their excess energy, aggression toward each other.

Table 4. The change in the mortality rate in pens with or without abrasive materials in the case of different genotypes during the 13-week study period (\%).

\begin{tabular}{cccccc}
\hline & $\begin{array}{c}\text { Commercial } \\
\text { Hybrid } \mathbf{a}_{\mathbf{1}}\end{array}$ & Maternal $\mathbf{a}_{\mathbf{2}}$ & Paternal $\mathbf{a}_{\mathbf{3}}$ & Prob. & Total \\
\hline $\begin{array}{c}\text { Pen with abrasive material } \\
\text { Pen without abrasive }\end{array}$ & $0.00^{\mathrm{a}}$ & $15.38^{\mathrm{b}}$ & $2.91^{\mathrm{a}}$ & $<0.001$ & 6.07 \\
$\begin{array}{c}\text { material } \\
\text { Prob. }\end{array}$ & 9.43 & 5.71 & 12.38 & 0.246 & 9.18 \\
Total & 0.001 & 0.023 & 0.011 & - & 0.142 \\
\hline
\end{tabular}

$\mathrm{a}, \mathrm{b}$ indicate significant differences among the different genotypes $(p<0.05)$.

In contrast, the maternal genotype had three times the mortality rate in pens equipped with abrasive material than in the control groups (C2). The commercial hybrid had no mortality in pens with beak-abrasive material, and the paternal genotype had only a quarter of what was experienced in the control flock (C3).

\section{Conclusions}

Based on the results of the study, it can be concluded that the insertion of beak-abrasive materials increased the behavioral repertoire of hens, which is particularly beneficial from an animal welfare point of view. This enriching element has been used extensively by animals, probably because the beak-abrasive material has aroused the interest of the birds, occupied them while consuming its ingredients. During the study period, the weight loss of the abrasive material was the highest in the paternal genotype (56.6\%), which was significantly higher than in the maternal line (29.6\%) and the commercial hybrid (27.4\%). Presumably, the reason for this is to be found in the different genetic backgrounds of the studied herd, in their different blood temperatures. The scratching area, where the beakabrasive material was suspended, was most used by laying hens in the time interval from 17:00 to 21:00. In the period from 17:00 to 21:00, the hens used the beak-abrasive materials the most, because the proportion of other behaviors has already decreased by this period, as the laying of eggs were mainly in the morning, the feed runs out of feeders, that is why the eating and drinking are greatly reduced. The duration of the dealing with the abrasive material showed fluctuations during the day. In the morning, there was less interest in the abrasive before feeding, while after 16:00, the animals were more and more often used the abrasive material, even for periods longer than $15 \mathrm{~s}$. Based on the phenomenon, it can be stated that within a day, over time, the length of use of the beak wearer increased. Insertion of the beak-abrasive material reduced mortality in genotypes that used them to a higher extent (commercial hybrid, paternal offspring group) of beak-abrasives because they produced significantly fewer mortality than their counterparts in the control group. Based on the preliminary results, it is clear that a full evaluation of several study days is needed to gain further and deeper conclusions. Consideration should be given to the use of an object of a different composition or enrichment that provides a better understanding 
of the background of poultry behavior during alternative housing of hens, as full open-air housing solutions are not available due to the risk of avian influenza and the cost of freerange. Further and longer-term research is needed to determine whether the insertion of the beak-abrasive block into the scratching area has a beneficial effect on the mortality data of the experimental groups through enrichment, either through physical abrasion of the beak or both.

Author Contributions: Data curation, A.R.; Formal analysis, T.P.F. and Z.S.; Investigation, T.P.F., E.G. and Z.S.; Resources, A.O.; Supervision, S.S. and Z.S.; Validation, T.P.F.; Visualization, T.P.F.; Writing—original draft, T.P.F. and Z.S.; Writing—review and editing, T.P.F. and S.S. All authors have read and agreed to the published version of the manuscript.

Funding: This research was funded by the Hungarian State, grant number 2018-1.3.1-VKE-2018-00042. The publication is supported by the EFOP-3.6.3-VEKOP-16-2017-00008 project.

Institutional Review Board Statement: All animals were handled according to the principles stated in the Directive 2010/63/EU regarding the protection of animals used for experimental and other scientific purposes [26].

Informed Consent Statement: Not applicable.

Data Availability Statement: The data presented in this study are available on request from the corresponding author. The data are not publicly available due to sensitive data about some pedigree lines.

Conflicts of Interest: A.O. is the employee of the Bábolna TETRA Ltd., which is the owner of the examined genotypes and the provider of the beak-abrasive materials. The remaining authors declare no conflict of interest. The funders had no role in the design of the study, in the collection, analyses, or interpretation of data, in the writing of the manuscript, or in the decision to publish the results.

\section{References}

1. Zomborszky, Z.; Budai, Z.; Milisits, G.; Szász, S.; Farkas, T.P.; Ujváriné, J.; Horn, P.; Sütő, Z. Eltérő genetikai hátterú, tojó típusú, csőrkurtítatlan jérce állomány nevelés alatti és tojóházi kiesésének elemz̋o vizsgálata, különös tekintettel az agresszióra. In XXI. Kaposvári Baromfitenyésztési Szimpózium, Kaposvár, Hungary, 29 September 2018; Sütő, Z., Ed.; Faculty of Agricultural and Environmental Sciences, Kaposvár University: Kaposvár, Hungary, 2018; pp. 78-87.

2. Banks, E.M. Social organization in Red Jungle fowl hens (Gallus gallus subsp.). Ecology 1956, 37, 240-248. [CrossRef]

3. Horn, P. A Baromfitenyésztők Kézikönyve; Mezőgazdasági Kiadó: Budapest, Hungary, 1981; pp. 137-189.

4. Niebuhr, K.; Zaludik, K.; Gruber, B.; Thenmaier, I.; Lugmair, A.; Troxler, J. Epidemiologische Unter-suchungen zum Auftreten von Kannibalismus und Federpicken in alternativen Legehennenhaltungen in Österreich. In Endbericht Forschungsprojekt; Nr. 1313 ITT; University Vienna: Vienna, Austria, 2006. [CrossRef]

5. $\quad$ Rodenburg, T.B.; Van Krimpen, M.M.; De Jong, I.C.; De Haas, E.N.; Kops, M.S.; Riedsrta, B.J.; Nicol, C.J. The prevention and control of feather pecking in laying hens: Identifying the underlying principles. World's Poult. Sci. J. 2013, 69, 361-373. [CrossRef]

6. Damme, K. Der Einfluß der Herkunft und des Schnabelkupierens auf die Leistung, Befiederung und Nestakzeptanz verschiedener Weißlegehybriden in Bodenhaltung. Arch. Für Geflügelkunde 1999, 63, 93-99.

7. Nicol, C. Feather pecking and cannibalism. Adv. Poult. Welf. 2018, 175-197. [CrossRef]

8. Sepeur, S.; Spindler, B.; Schulze-Bisping, M.; Habig, C.; Andersson, R.; Beyerbach, M.; Kemper, N. Comparison of plumage condition of laying hens with intact and trimmed beaks kept on commercial farms. Arch Geflugelkd 2015, 79. [CrossRef]

9. Weeks, C.A.; Lambton, S.L.; Williams, A.G. Implications for Welfare, Productivity and Sustainability of the Variation in Reported Levels of Mortality for Laying Hen Flocks Kept in Different Housing Systems: A Meta-Analysis of Ten Studies. PLoS ONE 2016, 11, e0146394. [CrossRef] [PubMed]

10. Guesdon, V.; Ahmed, A.; Mallet, S.; Faure, J.; Nys, Y. Effects of beak trimming and cage design on laying hen performance and egg quality. Br. Poult. Sci. 2006, 47, 1-12. [CrossRef] [PubMed]

11. Cheng, H. Morphopathological changes and pain in beak trimmed laying hens. World's Poult. Sci. J. 2006, 62, 41-52. [CrossRef]

12. Breward, J.; Gentle, M.J. Neuroma formation and abnormal afferent nerve discharges after partial beak amputation (beak trimming) in poultry. Cell. Mol. Life Sci. 1985, 41, 1132-1134. [CrossRef]

13. Duncan, I.J.H.; Slee, G.S.; Seawright, E.; Breward, J. Behavioural consequences of partial beak amputation (beak trimming) in poultry. Br. Poult. Sci. 1989, 30, 479-488. [CrossRef]

14. Gentle, M.J. Cutaneous sensory afferents recorded from the nervus intramandibularis ofGallus gallus vardomesticus. J. Comp. Physiol. A 1989, 164, 763-774. [CrossRef] [PubMed]

15. Bestman, M.; Koene, P.; Wagenaar, J.-P. Influence of farm factors on the occurrence of feather pecking in organic reared hens and their predictability for feather pecking in the laying period. Appl. Anim. Behav. Sci. 2009, 121, 120-125. [CrossRef]

16. Dennis, R.L.; Cheng, H.W. Effects of Beak Trimming on Pecking Force. Int. J. Poult. Sci. 2010, 9, 863-866. [CrossRef] 
17. Angevaare, M.J.; Prins, S.; van der Staay, F.J.; Nordquist, R.E. The effect of maternal care and infrared beak trimming on development, performance and behavior of Silver Nick hens. Appl. Anim. Behav. Sci. 2012, 140, 70-84. [CrossRef]

18. Brown, N.S. The Effect of Host Beak Condition on the Size of Menacanthus Stramineus Populations of Domestic Chickens. Poult. Sci. 1972, 51, 162-164. [CrossRef]

19. Mullens, B.A.; Chen, B.L.; Owen, J. Beak condition and cage density determine abundance and spatial distribution of northern fowl mites, Ornithonyssus sylviarum, and chicken body lice, Menacanthus stramineus, on caged laying hens. Poult. Sci. 2010, 89, 2565-2572. [CrossRef]

20. Chen, B.L.; Haith, K.L.; Mullens, B.A. Beak condition drives abundance and grooming-mediated competitive asymmetry in a poultry ectoparasite community. Parasitology 2011, 138, 748-757. [CrossRef]

21. Carruthers, C.; Gabrush, T.; Schwean-Lardner, K.; Knezacek, T.D.; Classen, H.L.; Bennett, C. On-farm survey of beak characteristics in White Leghorns as a result of hot blade trimming or infrared beak treatment. J. Appl. Poult. Res. 2012, 21, 645-650. [CrossRef]

22. Blokhuis, H.J.; Van Der Haar, J.W. Effects of pecking incentives during rearing on feather pecking of laying hens. Br. Poult. Sci. 1992, 33, 17-24. [CrossRef]

23. Jones, R.B. Effects of early environmental enrichment upon open-field behavior and timidity in the domestic chick. Dev. Psychobiol. 1982, 15, 105-111. [CrossRef]

24. Huber-Eicher, B.; Sebö, F. The prevalence of feather pecking and development in commercial flocks of laying hens. Appl. Anim. Behav. Sci. 2001, 74, 223-231. [CrossRef]

25. Reed, H.; Wilkins, L.; Austin, S.; Gregory, N. The effect of environmental enrichment during rearing on fear reactions and depopulation trauma in adult caged hens. Appl. Anim. Behav. Sci. 1993, 36, 39-46. [CrossRef]

26. European Union. Directive (EC) no. 2010/63/EU of the European Parliament and of the Council of 22 September 2010 on the protection of animals used for scientific purposes. Off. J. Eur. Union 2010, 276, 33-79. 